\title{
Decentralization and Democracy in Indonesia: A Critique of Neo-Institutionalist Perspectives
}

\author{
Vedi R. Hadiz
}

\begin{abstract}
This article assesses some of the major premises of neo-institutionalist explanations of decentralization policy and practices, but focuses especially on the relationship between decentralization and democracy, in the context of the recent and ongoing Indonesian experience with decentralization. In the last two decades 'decentralization' has become, along with 'civil society', 'social capital' and 'good governance', an integral part of the contemporary neoinstitutionalist lexicon, especially that part which is intended to draw greater attention to 'social' development. The concern of this article is to demystify how, as a policy objective, decentralization has come to embody a barely acknowledged political, not just theoretical, agenda. It also suggests alternative ways of understanding why decentralization has often failed to achieve its stated aims in terms of promoting democracy, 'good governance', and the like. What is offered is an understanding of decentralization processes that more fully incorporates the factors of power, struggle and interests, which tend to be overlooked by neoinstitutionalist perspectives. The current Indonesian experience clearly illustrates the way in which institutions can be hijacked by a wide range of interests that may sideline those that champion the worldview of 'technocratic rationality'.
\end{abstract}

\section{NEO-INSTITUTIONALISM AND DECENTRALIZATION}

Decentralization has emerged in the last two decades as one of the most important topics in development policy and theory debates. Understood as 'the transfer of political, fiscal and administrative powers to subnational governments', the World Bank has observed that it is 'a global and regional phenomenon' and that 'most developing and transitional countries have experimented with it to varying degrees'. ${ }^{1}$ Indeed, decentralization is a key theme in the

I would like to thank Richard Robison, ISS, The Hague, Andrew Rosser, IDS, Sussex, and two anonymous reviewers, for constructive comments on earlier drafts of this article. I would also like to thank Kevin Hewison and Howard Dick for their encouragement and Safaruddin Siregar, Elfenda Ananda and Ridaya Laode for their help. An earlier version appeared as Working Paper no 47, Centre of Southeast Asian Studies, City University of Hong Kong. Funding for fieldwork, which is gratefully acknowledged, was provided by the Centre of Southeast Asian Studies, University of Hong Kong and the Faculty of Arts and Social Sciences, National University of Singapore.

1. See the World Bank's 'Decentralization Home Page' at: http://wwwl.worldbank.org/ wbiep/decentralization/about.html

Development and Change 35(4): 697-718 (2004). (C) Institute of Social Studies 2004. Published by Blackwell Publishing, 9600 Garsington Road, Oxford OX4 2DQ, UK and 350 Main St., Malden, MA 02148, USA 
'neo-institutionalist' development literature, a hefty proportion of which is attributable to the intellectual production lines of such development organizations as the World Bank and the American aid agency, USAID. As a school of developmental thinking that explains the history, existence and functions of a wide range of institutions (government, the law, markets, the family, and so on) according to the assumptions of neo-liberal economic theory, neo-institutionalism represents a variant of an orthodoxy that is ascendant within governments, international development agencies, and policy think tanks. It is an orthodoxy that increasingly dominates large sections of the social science community, especially as the methodologies of mainstream neo-liberal economics become increasingly absorbed by other social science disciplines, including sociology and political science (see Fine, 2001; Harriss, 2002).

This article assesses some of the major premises of neo-institutionalist explanations of decentralization policy and practices, but focuses especially on the relationship between decentralization and democracy. This is done particularly with regard to the recent and ongoing Indonesian experience with decentralization.

An underlying premise of the neo-institutionalist literature is that countries can 'choose' the most appropriate form of decentralization. ${ }^{2}$ Finding the 'right balance' of decentralization in various areas of governance, and settling on the right 'pace', thus appears to be a matter of good, rational, policymaking. This does not mean a complete unawareness of the politics of policymaking, but if invoked, it is largely viewed as a process whereby rational policy-makers neutralize vested interests that are an obstacle to the real business of technocratic weighing of policy options. By contrast, I will suggest here that policy-making in any area is fundamentally shaped by contests between competing interests and is essentially indicative of particular modes of distribution of power (Rodan et al., 2001: 15). I would also suggest that neo-institutionalists become entangled in an ambiguous relationship with democracy by implicitly privileging the non-political — indeed the antipolitical - in their theoretical framework. Their emphasis, in particular, on the political insulation of technocrats is particularly ironic given the supposition that decentralization leads to good governance practices involving wider public participation in development. In fact, the general thrust of neoinstitutionalist theory embraces democracy only insofar as technocrats (or technopols) can preside over policies unimpeded by the intervention of societal interests that might include that of labour or other sources of social democratic or more radical agendas. Political democracy is, therefore, protected from challenges to the vast inequalities in power and wealth embedded in free markets, while it simultaneously protects the rights of property (Robison and Hadiz, 2004). This world-view implicitly favours a kind of

2. See the World Bank's 'Decentralization Net' at: http://wwwl.worldbank.org/publicsector/ decentralization/Different.htm 
liberalism that in many ways is highly authoritarian in its political aspects (Jayasuriya, 2000).

The relationship between decentralization and democracy is, in any case, problematic at best. Nowhere is the ambiguous relationship more clearly illustrated than in the case of Indonesia following the fall of the so-called New Order regime of Soeharto (1966-98). Here, decentralization has had little bearing in terms of pushing forward a governance agenda based on transparency and accountability, as neo-institutionalists propose, but has been instrumental in the development of newly decentralized, predatory networks of patronage. The Indonesian case shows that what ultimately matters is not decentralization itself, but the system of power relations within which it is undertaken.

In other words, 'democratic decentralization' in the sense envisaged by theoretically sophisticated neo-institutionalist authors like Crook and Manor (1998) or Manor (2002), was not something that could have reasonably been expected to transpire in Indonesia, given the context of the broader system of power relations. While acknowledging the importance of power relations, such influential authors still tend to define the 'social and political context of democratic decentralization' in narrowly institutional and cultural terms. Thus, they cite the presence of a competitive party system, a free press, and a 'culture of accountability' as among the factors in successful 'democratic decentralization' (Crook and Manor, 1998: 302-3).

Indonesia's party system is now highly competitive, and the press is free - though no one is quite sure about how a culture of accountability actually emerges. Yet decentralization has not produced the kind of democratic results that neo-institutionalists like Crook and Manor imagine. The problem is that the institutions of democracy have been appropriated by many elements of the old rapacious, authoritarian regime. These have successfully reconstituted themselves as democratic actors via political parties and parliaments (Robison and Hadiz, 2004) over which they preside. A good example is the 'ruling' PDI-P (Indonesian Democratic Party for Struggle) of President Megawati Soekarnoputri. The party includes a range of former apparatchik, military men, entrepreneurs, and assorted political hustlers, peddlers and enforcers of the old New Order (ibid.). Moreover, even the free press in places like North Sumatra, discussed below, has partly been appropriated by political gangsters involved in extortion rackets to further the political aims of local alliances. ${ }^{3}$ Because Indonesia's democratization process has been hi-jacked by predatory interests - which 'reformasi' failed to sweep aside (ibid.) - the outcome of decentralization has been affected in ways largely unexpected in the neoinstitutionalist literature.

3. Interview with J. Anto, North Sumatran press watchdog, 17 July 2002. 


\section{WHY DECENTRALIZE?}

There have been many reasons cited for the policy emphasis on decentralization, globally. Among the reasons listed in the neo-institutionalist literature are:

(T)he advent of multiparty political systems in Africa; the deepening of democratization in Latin America; the transition from a command to a market economy in Eastern Europe and the former Soviet Union; the need to improve delivery of local services to large populations in the centralized countries of East Asia; the challenge of ethnic and geographic diversity in South Asia, as well as ethnic tensions in other countries (Bosnia and Herzegovina, Ethiopia, Russia) and the attempt to keep centrifugal forces at bay by forging asymmetrical federations; and the plain and simple reality that central governments have often failed to provide effective public services. (Litvack et al., 1998: 1)

Significantly, 'decentralization' has become, along with 'civil society', 'social capital' and 'good governance', an integral part of the contemporary neo-institutionalist lexicon, especially of those aspects which are intended to draw greater attention to 'social' development. Neo-liberal versions of the concept of civil society that inform the neo-institutionalist literature suggest that a vibrant civil society contributes to good governance and democratization by ensuring greater public participation in development. Crucially, decentralization is usually assumed to provide better opportunities for participation by local communities in decision-making. As the World Bank put it in a recent document entitled 'How We Work with Civil Society': 'Eleven years since the fall of the Berlin Wall we now approach economic reforms and the development process in a much more decentralized fashion. Individuals and various social groups are now seen not only as beneficiaries, but also as active forces supporting development'. ${ }^{4}$

In turn, a vibrant and healthy civil society itself can only really emerge through the nurturing of social capital - norms and values that bind people and communities together (Putnam, 1993, 2000) and create 'trust' among development actors as well as between those who govern and are governed. Decentralization, moreover, is said to potentially lead to greater prioritization of local needs in development policy, as it encourages greater accountability of those who govern to local communities. It can also enhance political stability, and even national unity. ${ }^{5}$ Thus, a glowing assessment (produced under the auspices of the Asia Society in the United States) of decentralization policy in the Philippines under the 1991 Local Government Code, claims that it has been responsible for greater public participation in development, enhanced levels of public accountability and local control over resources, even as the author acknowledges the role of predatory

4. World Bank, 'How We Work with Civil Society', online document available at: http:// lnweb18.worldbank.org/ECA/eca.nsf/Initiatives/A98CDE16184FEDFC85256BD6004F486F? OpenDcument.

5. See the World Bank's 'Decentralization Net' at: http://wwwl.worldbank.org/publicsector/ decentralization/Different.htm 
local political bosses (Rood, 1998). In the same vein, local control over development priorities and resources is one of the major objectives of the decentralization programme in Indonesia after more than thirty years of centralized authoritarian rule under Soeharto, partly as an antidote to local demands for autonomy that in some cases have been accompanied by the threat of secession.

According to a recent USAID document, 'Indonesia is moving rapidly from years of tight central control to a far more decentralized and autonomous system of local government'. More specifically, USAID suggests that the legal framework for local autonomy in Indonesia - part of a series of wider reforms of an array of institutions - is geared to help "create the basis for national and local democratic governance'. ${ }^{6}$ But it is also clear that the concern for public participation, accountability and even democracy, is in itself partly a response to criticism in the past of the support of international development agencies for technocratic and top-down development policies. Populist and radical critiques of such policies in many Southeast Asian countries have long claimed that they have resulted in an elitist development process within which large sections of society are marginalized (including peasants, workers, other urban poor, women, indigenous peoples, and so on), while a small elite is said to grow more powerful or wealthy in cahoots with international capital. In Indonesia, for instance, there is a long tradition of Islamic petty bourgeois populism expressed against the rapacity of big business, whether foreign or ethnic Chinese. There is also a long suppressed radical critique of the systemic injustices of capitalism that is rooted in the socialist tendencies of the country's nationalist, anti-colonial movement. ${ }^{7}$

There are also flaws in the conception of civil society. Neo-liberals and neo-institutionalists assume a civil society defined by a homogeneous, common set of fundamental interests, bound together by the nurturing of social capital. While these interests are often tacitly understood to favour free markets, rule of law, and democracy - and are thus basically associated with a hypothetically vibrant and independent middle class or bourgeoisie - such a view cannot account for the competing interests within civil society itself. Moreover, important sections of civil society may be profoundly anti-democratic or anti-market (Rodan, 1996: 4-5; White, 1994) including, ironically, the bourgeoisie and the middle class. By the same token, the notion of social capital - which actually began its life as part of a critique of the cultural aspects of class inequalities in contemporary capitalism (Bourdieu, 1986), but was appropriated by the followers of theorists such as Becker (1996), Coleman (1988) and Putnam (1993, 2000)

6. United States Agency for International Development (USAID), 'Transition to a Prospering and Democratic Indonesia', available online at: http://www.usaid.gov/id/ docs-csp2k04.html.

7. See Chalmers and Hadiz (1997), especially Chapters 5, 8, and 9. Also see Bourchier and Hadiz (2003), especially Chapters 3 and 6. 
- is at the very least ambiguous. Its main contemporary function appears to be the denial of social conflict and of the importance of unequal power relations in determining development trajectories. The notion of social capital, therefore, has become an essential part of the wider technocratic project of conceptually depoliticizing development (Fine, 2001; Harriss, 2002).

It is no wonder then that the World Bank fails to acknowledge the importance of social conflict even as its effort to link up with civil society - for example, through NGOs - is supposed to 'amplify the voices of the poorest people in the decisions that affect their lives' (World Bank, 2000: 5). This is due to its underlying philosophy that assumes voluntary transactions by rational individuals. Thus, the Bank itself defines civil society as the 'space among family, market and state; it consists of not-for-profit organizations and special interest groups, either formal or informal, working to improve the lives of their constituents' (ibid.: 10). Moreover, an array of organizations research and policy design organizations, labour unions, the media, NGOs, grassroots associations, community-based organizations, religious groups and many others - are regarded within this definition as 'typical examples of the actors that comprise the dynamic web known as civil society' (ibid.).

While there is certainly nothing wrong with recognizing the innate diversity in civil society, there is no acknowledgement that the 'dynamic web' may consist of elements that are mutually antagonistic, of the powerful and the exploited, which for example, may support or resist the sort of policy agendas promoted by international development agencies or their domestic allies in developing societies. By painting a rosy picture of civil society, neoinstitutionalists can overlook the fact that democracy, public participation, accountability and social and economic rights are all historically tied to the outcome of struggles of social forces and interests and are not simply the product of intentional policy design. Liberal democratic regimes in the West, for example, are the product of grinding social change over centuries, coloured by often violent and bloody confrontations, not the least between social classes.

Ignoring such histories, a survey of decentralization and democratization in Southern Africa (Wunch, 1998) cites studies that show how 'democracy must be rooted in functioning local, participatory self-governance institutions', pointing to 'untapped local capacity to make collective choices and take collective action'. The dilemma for the author of the survey is having to admit that 'experiments' in local governance and democracy in virtually every place in Africa have failed. Citing other studies, he opines that these failures are rooted in 'specific policy choices and strategies pursued by African governments', which include the deliberate withholding of resources from 'local entities'. Nevertheless, Wunch suggests a 'not discouraging picture' emerging from the cases of South Africa, Swaziland, and particularly, Botswana - as long as 'such unknowns' as 'political will, good luck and astute leadership' are present. Again, we see here the penchant for downplaying how policy choices, including those involving the allocation 
and distribution of resources, are primarily a matter of conflict and contestation. Not surprisingly, a favourable prognosis is finally hinged upon intangible 'unknowns'.

Another analysis of the link between decentralization and democracy, this time focusing on the Philippines experience (Rood, 1998), suggests that socio-economic developments leading to a more mature and globalized middle class are resulting in better governance practices, in spite of the entrenched presence of local political bosses that regularly deploy 'guns, goons and gold', and whose position has been further bolstered by post-Marcos-era decentralization processes. Rood argues that these socio-economic changes, along with generational shifts in ruling political families, is resulting in a change in mind-set among elites, from a traditional to a more modern and technocratic one. Thus, he points to a case in which the son of a notorious old local boss is 'an American-educated sophisticate quite at home with technocratic modes of governance'. Apart from unwittingly revealing an ideological preference for 'rule by technocracy' and by Western-influenced 'sophisticates', this assessment is contradicted by another long-time analyst of predatory politics in the Philippines who suggests that members of well-established political clans continue to dominate such bodies as the House of Representatives, and that elections are still tainted by the power of money and intimidation (Hutchcroft, 1998). Hutchcroft also notes that 'the enormous expense of running for election serves as an effective barrier to the entrance of reformist forces into the political arena', and that 'many so-called new faces often retain strong connections to old centers of power'. As we shall see, such observations are directly relevant to the Indonesian case discussed at length below.

What follows in the remainder of this article is not a critique of decentralization which focuses merely on the disjuncture between the concept and the actual implementation. My concern is to demystify how, as a policy objective, decentralization has come to embody a barely acknowledged political, not just theoretical, agenda. What is offered, thus, is an understanding of decentralization processes that more fully incorporate the factors of power, struggle and interests. The point is to suggest alternative ways of understanding why decentralization has often failed to achieve its stated aims, partly by focusing on the Indonesian experience, and to relate this to the idea that institutions can be captured and appropriated by a wide range of interests which may, in the process, sideline those that champion the worldview of 'technocratic rationality'.

\section{THE PROBLEMS OF DECENTRALIZATION: SOME EXPERIENCES FROM INDONESIA}

It has been noted that a major problem confronting neo-institutionalists is that decentralization does not always work in the way it is supposed to. The 
neo-institutionalist answer to the question of failure inevitably emphasizes the shortcomings of weak institutions, the inappropriate design of decentralization programmes, or the lack of commitment among political elites. Not surprisingly, the suggested remedy almost always relies on institutional adjustment and tinkering. There is little account taken of the fact that the persistence of weak institutions may, for instance, benefit powerful predatory interests under certain conditions, or that the particular design of decentralization may reflect a certain constellation of power rather than some imagined objective common good.

For example, an essential question from a good governance and neoinstitutionalist perspective is whether fiscal decentralization results in more or less corruption, or more or less efficient allocation of resources. A technical solution that has been advanced in relation to post-Soeharto Indonesia, to cite one case in point, is to carefully plan the sequencing of decentralization over a longer period of time to allow for institutional finetuning at the different levels of governance (Ahmad and Hofman, 2000). This has been a response to very real fears that local officials and notables may take advantage of decentralization by establishing local fiefdoms fed by decentralized corruption.

In many ways this response recalls the arguments put forward in the 1980s and 1990s suggesting that the problems of Indonesia's economic deregulation lay in its improper sequencing (World Bank, 1996: xxvii). However, rather than being a technical error, the sequencing of deregulation was effectively determined by the actual configuration of salient state and business interests affecting economic policy-making. Thus, deregulation sequencing was primarily a question of power, the consequence of which was that certain economic sectors - those in which there were powerful vested interests in the maintenance of monopolies, for example - were less open than others to deregulation (Robison and Hadiz, 2002: 48). Likewise, as discussed in greater detail below, decentralization policy in Indonesia after Soeharto is also a matter of power; of contestation by an array of powerful interests, national and local, many of which seek to preserve old predatory relations, but within a new, decentralized and democratic political format.

However, it would be unfair to suggest that the problems encountered in actual decentralization experiences have not led to a great deal of caution among neo-institutionalist authors. In fact, some have been careful to underline that decentralization is not necessarily a panacea for developing countries. The World Bank, for example, on its 'Decentralization Net', cautions that decentralization 'may not always be efficient, especially for standardized, routine, network-based services'. It can also 'result in the loss of economies of scale and control over scarce financial resources by the central government'. In fact a central theme has been a wariness that 'weak administrative or technical capacity at local levels may result in services being delivered less efficiently and effectively in some areas of the country'. 
As has been evident in the recent Indonesian experience, 'Decentralization can sometimes make coordination of national policies more complex' and may allow functions to be captured by local elites. But the policy advice dispensed should things go wrong is disarmingly simple, typically boiling down to finding the 'appropriate balance of centralization and decentralization' that is 'essential to the effective and efficient functioning of government'.

That the actual balance between central and regional authority is not just about a conscious division of labour but also about concrete struggles over political and economic resources is illustrated in Indonesia, where decentralization has resulted in confusion about the distribution of power and authority between different levels of government. Rather than a technical governance issue, the confusion stems from a tug of war between competing interests which has a concrete, material basis. Powerful coalitions entrenched in Jakarta retain a vested interest in maintaining some control over local resources and authority over taxes, royalties and investment policy, while attempting to balance this against aspirations for greater local autonomy. On the other hand, local elites (especially at the subprovincial level) are intent on taking direct economic control, typically citing the injustice of past practices that allowed Jakarta to exploit Indonesia's vast riches. In the meantime, provincial authorities are stuck in the middle, struggling to retain some power and not to fall into the oblivion of political and administrative redundancy. The result: rather than breaking up centralized state intervention and promoting investment, decentralization has so far opened the door to a host of uncertainties which frighten investors.

\section{KEEPING POLITICS OUT OF DECENTRALIZATION}

The World Bank's 'Decentralization Net' declares that 'the success of decentralization frequently depends heavily on training for both national and local officials in decentralized administration'. ${ }^{9}$ This 'training for success' explanation is in fact an admission that a neo-liberal agenda is not going to be driven by a progressive civil society, but must be enforced by technocratic and managerialist interests constructed within the state bureaucracy. Clearly there is much in common here with old-style modernization theory that relied on the rationality, good will and intelligence of (a Western-trained) modern, technocratic and bureaucratic elite.

8. See the World Bank's 'Decentralization Net' at: http://www1.worldbank.org/publicsector/ decentralization/Different.htm

9. See the World Bank's 'Decentralization Net' at: http://www1.worldbank.org/publicsector/ decentralization/Different.htm 
A recent USAID document on decentralization in Indonesia replicates this 'training for success' idea. According to this document:

local governments have little experience with participatory self-rule and will need assistance to create adequate mechanisms for participation, transparency and accountability. They also have limited technical capacities, particularly to perform functions that have been provided by central agencies, and they will need assistance to demonstrate to citizens that autonomy does lead to improvements in services and the environment. Particular attention will be paid to ensure women's participation and concerns are included at all levels. ${ }^{10}$

What is striking here is that there is no mention of the lack of power and influence of local environmental lobbies, or of the women's movement in Indonesia. There is also no mention of how, in the Indonesian context, big domestic and foreign corporations can ride roughshod over environmental regulators, or that young female workers in low wage manufacturing industries continue to face harassment and violent intimidation as they attempt to exercise their right to organize.

It should be noted that the World Bank and other organizations have invested a lot of resources into decentralization programmes around the world. Thus they have an ever-increasing institutional stake in their success. According to Litvack et al. (1998), a growing number of Bankfunded projects are in effect supporting decentralization schemes: 12 per cent of Bank projects completed between 1993 and 1997, for example, have involved decentralizing responsibilities to lower levels of government, including through the direct provision of loans to sub-national governments (ibid.: 1). In ensuring the 'success' of these decentralization programmes, the Bank no doubt has to work with an array of entrenched elites, both national and local. This in itself restricts any serious consideration of the factors of power, interest and conflict in the theoretical approach. The result is a theory of decentralization that tacitly endorses the non-disturbance of the existing social order to the greatest extent possible, while encouraging institutional tinkering in a supposed political vacuum.

However, the absence of politics is not just a concession to entrenched elites, for it is equally self-serving. Technocrats benefit from the notion of a global corps of well-trained experts who are able to identify the common good through rigorous scientific procedure (mostly associated with economics) and to rise above petty self-interest. This allows the Bank itself - and by implications its domestic allies - to deny that they are part of a global coalition of power and interests whose agenda often coincides with that of the most globally mobile sections of corporate capital.

10. United States Agency for International Development (USAID), 'Transition to a Prospering and Democratic Indonesia', available online at: http://www.usaid.govid/ docs-csp2k04.html 


\section{THE POLITICS OF DECENTRALIZATION ${ }^{11}$}

The technocratic, neo-Platonian world-view is frequently challenged when policies go askew or result in unintended consequences, and is disrupted when institutions - such as those designed to facilitate economic deregulation, central bank autonomy, or decentralization - do not work the way they are supposed to. Liberal technocrats can be sidelined or forced to accommodate competing agendas if a viable domestic social base of power - especially for economic liberalism - is lacking. This has been the case in Indonesia since 1998.

The unravelling of the long-entrenched Soeharto regime in the wake of the Asian economic crisis of 1997-98 set the stage for the emergence of a new political framework within which political parties, parliaments (national and local) and elections have become increasingly important as arenas of genuine political contestation. As central authority has eroded, power has been decentralized from the executive body of government to the legislative branch, and from Jakarta to the regions. In the new democratic context, openly-expressed desires for more local autonomy in a host of regions, and in some cases even for secession (Malley, 2001), demanded an urgent response. There had been regional expressions of discontent even during the Soeharto era, including separatist movements in Aceh, Papua and newly-independent East Timor, but these were often simply suppressed by the use of brute military force. As the New Order's institutional framework disintegrated, however, a reaction based purely on violence was no longer possible. The main response of Soeharto's successors to regional demands, by contrast, took the form of new legislation on local autonomy drafted in 1999 and enacted in January 2001. USAID described the laws as follows:

The first of these laws, Law 22/1999, assigns to central government only key national functions such as defense, judiciary, foreign relations and the monetary and fiscal system, while devolving most authorities directly to local governments (city and district). The roles of provinces were minimized, restricted largely to inter-district functions and governance and management of deconcentrated central government functions. The law gives local government great autonomy over most of the functions that affect people most directly, including urban services, primary and secondary education, public and basic health services, environmental management, planning and local economic development. ${ }^{12}$

In the same document, USAID notes that the 'second decentralization law, Law 25/1999, provides the fiscal framework for local government, emphasising local financial decision-making'. However, it also correctly

11. In what follows, much of the empirical evidence from Indonesia is taken from Hadiz (2003).

12. United States Agency for International Development (USAID), 'Transition to a Prospering and Democratic Indonesia', available online at: http://www.usaid.gov/id/ docs-csp2k04.html 
observes that there remain contentious issues relating to such matters as generating local government revenue, determining central government subsidies, and dividing up revenue from natural resource based industries between central and local government (ibid.). The latter is an especially important issue in resource-rich provinces such as Aceh, Riau, East Kalimantan and Papua.

As the USAID report comments, the regional autonomy legislation in question provides greater powers for authorities at the sub-provincial level - the kabupaten (regency or district) and kotamadya (city or town) - rather than at the provincial level. However, recent indications suggest that further amendments would change the balance of power by providing more local autonomy at the provincial rather than sub-provincial level. Such a change would strengthen the position of provincial governors, but frustrate the quickly-rising ambitions of scores of bupati (regents) and mayors. At the same time, it would satisfy Jakarta officials' resolve to maintain as much control as possible over the resources of the country as a whole. From their point of view, it is easier to deal with a few dozen governors than several hundred bupati and mayors at the sub-provincial level. These mayors, bupati, and other regional officials, meanwhile, see the possible revisions as a step backward, and a sign of the lack of genuine political commitment to decentralization on the part of the government of President Megawati Soekarnoputri. ${ }^{13}$

The immediate result of this tug-of-war, however, is a high degree of uncertainty and ambiguity about the whole business of governance. According to North Sumatra governor T. Rizal Nurdin, for example, he now has the capacity to annul local ordinances produced by sub-provincial executive and legislative bodies, including those that have to do with the contentious introduction of new forms of taxation and levy. ${ }^{14}$ Officials at the subprovincial level, however, who tend to see the governor as a mere representative of Jakarta rule, often dispute this reading of the rules of the game.

Investors, both domestic and foreign, also have a hard time deciphering these new rules. A foreign investor with no experience of dealing with Indonesia might now be especially perplexed. There is little consensus about whether local autonomy laws require permission to invest from Jakarta, the province, or the sub-provincial level of government. ${ }^{15}$ Given

13. The President has a reputation as a staunch nationalist who is opposed to devolving too much power to the regions for fear of national disintegration.

14. Interview with T. Rizal Nurdin, North Sumatran governor, 7 July 2001.

15. I found this to be the case during fieldwork in North Sumatra. Officials at different levels of government would privilege the role of their respective institutions in 'facilitating' investment. Abdul Hafid, the bupati of Deli Serdang — a major manufacturing centre as well as the site of sizeable plantations - was particularly adamant that he had absolute authority to do what he wished with most investment applications. Interview, Abdul Hafid, 7 September 2001. 
the breadth and depth of corruption in Indonesia, ${ }^{16}$ this potentially means that an investor has to provide kickbacks to a number of individuals and offices at different levels of Indonesia's notoriously cumbersome bureaucracy, with relatively little guarantee that he is bribing the right ones. ${ }^{17}$ For a host of local officials, the situation presents opportunities to break into a lucrative, but previously Jakarta-centred, 'industry'.

Thus, although it is easy to be distracted by the much-used language of local pride or ethnic or regional identity, the contest in Indonesia has clearly been about control over authority and resources. The stakes involved vary from region to region in the vast Indonesian archipelago, being particularly significant in natural resource-rich areas like the kabupaten of Kutai in Kalimantan, and other places such as centres of manufacturing production. But even local officials presiding over relatively resource-poor regions would want to ensure greater direct power over whatever is available locally rather than resign themselves to control by Jakarta. Hence, the way that regional autonomy and decentralization is being implemented is ultimately a matter of political contestation.

One example of this is the institution of new levies to businesses and the public. In Medan, North Sumatra, for instance, local politicians have been busy introducing new levies, much to the distress of the local business community. ${ }^{18}$ One local parliamentarian, Bangkit Sitepu, suggests that business people are merely being asked to give back to society some of the profits they have enjoyed, ${ }^{19}$ but many local business people argue that a stream of new levies - combined with incalculable unofficial kickbacks will burden business and further discourage investment. ${ }^{20}$ The central government has ordered lower level administrators to revoke fifty-two local laws and ordinances that were deemed to hamper business activity (Straits Times, 25 April 2002). Local politicos also toyed with the idea that regional administrations should be allowed to borrow money from overseas (Simandjuntak, 2003), but the idea was quashed by the central government in early 2003, no doubt to the relief of such organizations as the IMF, which were fearful of local financial mismanagement.

16. Transparency International placed Indonesia in joint third place in its list of most corrupt countries in the world in its 2001 survey, and joint fourth in 2002 (see Internet Centre for Corruption Research, http://www.gwdg.de/ uwvw/icr.htm). Indonesia regularly scores poorly in such surveys: in 2000, the Hong Kong-based Political and Economic Risk Consultancy (PERC) released results that showed expatriates working in Asia viewing Indonesia as the most corrupt of Asian countries (see Kompas, 2000).

17. As Max Weber once observed, it is this sort of unpredictable corruption that is likely to be the most economically detrimental; see Weber (1978: 240, 1095).

18. Interview with Yopie Batubara, head of the North Sumatra Chamber of Commerce and Industry, 8 September 2001.

19. Interview with Bangkit Sitepu, 16 July 2002.

20. Interviews with Yopie Batubara, 8 September 2001, and Soerya Sampoerna, 6 July 2001. 
In spite of the issue of corruption at the local level, the problem remains that sub-provincial units of governance are under some pressure to quickly develop new sources of local revenue. This is an issue especially for districts that are not well-endowed with natural resources or whose natural resources remain under the jurisdiction of the central government under existing legislation, and for cities or towns that are not major manufacturing or business hubs. In North Sumatra, sub-provincial politicians are particularly concerned to ensure local control over revenue from the plantations sector. Similarly, local politicians want to take control of such assets as Polonia Airport in the provincial capital city of Medan, the harbour at Belawan, and the Tirtanadi water supply company, in order to gain authority over related levies and taxes. ${ }^{21}$ According to current legislation on decentralization, these potentially important economic resources do not fall under the jurisdiction of sub-provincial administrators. It is interesting to note that environmental activists in North Sumatra are concerned that the predatory nature of local business and bureaucratic interests is likely to further harm, rather than help protect, the environment. ${ }^{22}$

The result is a very messy state of affairs. In Medan, for example, municipal government officials confide that the organizational structure of government has not been revamped to meet the requirements of regional autonomy and that much improvisation has been necessary to keep the government machinery running. ${ }^{23}$ The top development planning career bureaucrat in Sleman, Yogyakarta, conceded that he had little idea of the financial ramifications of regional autonomy just a few weeks before its official implementation in January $2001 .{ }^{24}$ In the midst of such confusion, provincial and sub-provincial officials routinely quibble about jurisdiction over particular taxes and levies, which spill over to questions about the provision of essential public services like water and electricity supply. ${ }^{25}$ Such conflicts between provincial and sub-provincial authorities has been one of the main problems in the implementation of decentralization so far. ${ }^{26}$ The governors of North Sumatra and Yogyakarta, for example, have lamented how notionally subordinate bupati at the sub-provincial level have increasingly come to defy their authority. ${ }^{27}$

21. Interviews with Medan city parliamentarians Bangkit Sitepu and Moses Tambunan, 16 July 2002 .

22. Interview with Effendi Pandjaitan, 18 July 2002.

23. Interview with Lasmi, government administration section, Mayor's Office of Medan, 3 September 2001.

24. Interview with Sutrisno, Regional Secretary and head of the Regional Development Planning Body, Sleman, 9 December 2000.

25. Interview with Ridwan Lubis, academic, 16 July 2002.

26. Interviews with Marin Purba, Mayor of Pematang Siantar, 7 September 2001, and Syamsul Arifin, bupati of Langkat, 5 September 2001.

27. Interviews with Sri Sultan Hamengkubuwono, Governor of Yogyakarta, 15 December 2000, and T. Rizal Nurdin, Governor of North Sumatra, 7 July 2001. 
It is important to reiterate that the primary problem is neither the faulty design of the decentralization process itself, nor a lack of commitment to implementing decentralization. That the design is faulty is beyond doubt, as reflected in numerous legal contradictions and ambiguities about the functions and role of different levels of government under the current legal framework (Bell, 2001); but rather than the product of incompetence per se, the design - faults and all - is indicative of a particular constellation of power and interest in the wake of the New Order.

The most notable aspect of this constellation is that predatory interests nurtured under the Soeharto regime's formerly vast, centralized system of patronage - which extended from the Presidential palace in Jakarta down to the provinces, towns and villages - have largely survived and remain intact (Robison and Hadiz, 2004). They have reconstituted themselves through new alliances, nationally and locally, and captured the institutions of Indonesia's democracy to further their own objectives. Through control over parliaments and political parties, and via business alliances and assorted instruments of political violence - a confusing array of paramilitary groups and crime/'youth' organizations — they are establishing newly decentralized, competing, and sometimes overlapping networks of patronage (Hadiz, 2003). In short, decentralization is facilitating the emergence of more localized patronage networks that are relatively autonomous of central state authority.

The result is that those who champion decentralization in Indonesia as a step toward an imagined benevolent, 'modern' technocratic governance have been sidelined from the political contest. In the absence of viable liberal or social democratic organized interests and parties, which might support reform agendas based on the rule of law and accountability, the decentralization process has been effectively captured by predatory interests. The problem is not an absence of civil society bound together by social capital; civil society does exist, but the most powerful elements in the country are those that were organized and nurtured under a rabidly plundering regime. This point will be elaborated in the more detailed discussion below.

\section{WHAT KIND OF DECENTRALIZATION AND DEMOCRACY?}

Decentralization and democratization in Indonesia have been characterized by the emergence of new patterns of highly diffuse and decentralized corruption, rule by predatory local officials, the rise of money politics and the consolidation of political gangsterism. In the Indonesian context, the main question to ask, therefore, is who has benefited most from this decentralization and this type of democratic system?

It is not difficult to identify the beneficiaries. By and large, they are individuals and groups who had earlier functioned as the local operators and apparatchik of the previous New Order — small to medium-size, but 
politically well-connected business people with big ambitions, as well as an array of the regime's former henchmen and enforcers. In the major manufacturing centre of Medan in North Sumatra, political gangsters and bosses of paramilitary groups seem to be exerting a great deal of influence as a result of their role in, for example, securing local electoral victories. All such individuals and groups essentially represent interests incubated within the lower layers of the New Order's formerly vast system of patronage. Because of the opportunities provided by decentralization and democratization, they have now moved a few rungs up the political ladder. Once nurtured by a highly authoritarian regime that has since unravelled, these local predatory interests are now thriving under Indonesia's newly decentralized and democratized political system. They have found that the local institutions of democratic governance, once captured, can provide the protection of their interests that previously required centrally organized authoritarian controls and a repressive military apparatus. They have also found that the politics of money and political violence can be potent tools in securing their position.

Many people believe that much of the abuse of power and the systematic 'KKN' (the Indonesian acronym for 'corruption, collusion and nepotism') that took place in Jakarta has now simply shifted to the local level. In truth, this was not unexpected. One provincial parliamentarian in Yogyakarta, for example, had predicted that local autonomy 'will be followed by the decentralization of KKN practices' ${ }^{28}$ Another observed just before the enactment of the decentralization laws that the new prominence of local legislatures simply means that 'deviation that used to occur in the bureaucracy' will now take place in the local parliaments. ${ }^{29}$

The Indonesian case is not unique: there are many countries in which predatory elements of civil society, including political gangsters, have been major players in decentralized democratic political life. Post-Soviet Russia provides one of the better examples; the Philippines case mentioned earlier is another; and Thailand a third. In Thailand, constitutional changes from 1997 have stipulated a more decentralized structure of governance. There has been a drive to create new municipalities, now endowed with greater power and responsibilities (Patpui, 1999). In the words of the Asian Development Bank, the aim is to 'reconfigure the political, legislative, judicial and administrative machinery of government. If successful, Thailand will move to a more decentralized and participatory structure, in which government institutions at all levels will operate in a more transparent, accountable and responsive fashion' (ADB, 1999: 7). The ADB, however, recognizes that in the Thai case a 'number of influential forces have a vested interest in the status quo', and that 'the practice of vote buying in rural areas, fierce

28. Interview with Khairuddin, head of the Golkar faction in the Yogya provincial parliament, 5 January 2001.

29. Interview with Syukri Fadholi, then head of the PPP faction in the Yogya provincial parliament, 15 December 2000. He is now Deputy Mayor of the city of Yogyakarta. 
bureaucratic resistance to the decentralization initiatives envisioned in the constitution, and widespread perceptions of corruption' are all obstacles to success. Nevertheless, it still assumes that such success is possible, in true neo-institutionalist fashion, simply on the basis of 'careful planning and tenacious implementation' (ibid.).

In fact, power was always more decentralized in Thailand than in New Order Indonesia, even during the long periods of autocratic military rule (the same is true of the Philippines under Marcos, who tried to centralize power at the expense of local oligarchs). Moreover, the advent of parliamentary democracy in Thailand in the 1980s had already been accompanied by the growing influence of local political and business alliances - headed by individuals known as chao pho - who were by definition involved in underworld activities. ${ }^{30}$ As in Indonesia today, many of these chao pho, or their family members, have entered politics and been elected as parliamentarians, town mayors or village heads. ${ }^{31}$ Thus in many ways, the postSoeharto Indonesian trajectory parallels developments that have already occurred in Thailand.

As in Thailand, local legislative bodies in Indonesia have become particularly crucial sites of political battles in recent years. This is especially true in Indonesia during the election of new bupati or mayors, which under the existing system falls under the purview of sub-provincial parliamentarians. In Yogyakarta, there was evidence of this in the election of the bupati of Sleman in 2000, a nasty affair characterized by both money politics and the intimidation by competing candidates of the supporters of their rivals. There were widespread claims of beatings, kidnappings, the use of paramilitary organizations, and bomb threats. ${ }^{32}$ In the province of North Sumatra, the election of the bupati of Karo turned into a fraught process, involving such events as the unexplained burning of the local parliament house. ${ }^{33}$

But it was the election in March 2000 of local business figure Abdillah as Mayor of Medan, the capital city of North Sumatra, that has been among the most heavily scrutinized of cases. It involved a contest, interestingly, between an established businessman and an established career bureaucrat, neither of whom could boast pro-reform reputations in the area of governance. The businessman, Abdillah, finally defeated the bureaucrat, Ridwan Batubara, after a hard-won, bitter process, allegedly involving bribery and

30. These are rich businessmen who own land, rice and sugar mills, liquor breweries, and tobacco farms, but are also engaged in criminal activities like gambling, drugs and prostitution.

31. See the collection of articles in McVey (2000).

32. Interview with Hafidh Asrom, businessman and defeated candidate for the bupati-ship of Sleman, 9 December 2000.

33. Interview with John Andreas Purba, PDI-P member of Karo sub-provincial parliament, 6 July 2001. 
violence. Initially disadvantaged by the fact that Ridwan had received the support of the PDI-P, the largest faction in the municipal parliament that elects the mayor, Abdillah apparently resorted to bribing large numbers of PDI-P parliamentarians to switch allegiance. At least, under pressure from Ridwan's supporters, a number of parliamentarians eventually confessed to receiving bribes. At the same time, Ridwan's brother, businessman Yopie Batubara, claims to have also offered monetary incentives to parliamentarians to support Ridwan, who had the backing of the PDI-P central leadership in Jakarta. ${ }^{34}$

However, Abdillah did not depend just on money to get elected: his candidacy was also helped along by the mobilization on his behalf of a group of 'toughs' led by Martius Latuperisa, a Medan parliamentarian who also heads the local branch of the innocuously named FKPPI - the Communication Forum for Sons and Daughters of Military Retirees. Latuperisa's mob was apparently instrumental in getting PDI-P parliamentarians to switch to Abdillah's side, asking them to choose between 'the money or the gun'. ${ }^{35}$ The FKPPI, formerly with links to the Soeharto family and the military, and with a widespread network of political operators and thugs, proved to be a useful tool of intimidation.

Cases like the mayoral election in Medan indicate the prominence of money and intimidation in Indonesia's more decentralized and democratic politics. Yopie Batubara estimates that a candidate needs tens of billions of rupiah to successfully win a local election, ${ }^{36}$ while a defeated candidate for bupati in South Tapanuli says that a successful bid there would require an investment of Rp 2 billion (approximately US\$ 220,000), instantly disqualifying many potential reformers with little financial backing. ${ }^{37}$ It is also worth noting that local entrepreneurs have begun directly contesting local elections in Indonesia, as they have been doing for some time in Thailand. In North Sumatra alone, no less than six of the twenty-two bupati or mayors elected since the fall of Soeharto have a background in business.

It is also clear that political thuggery has gone together with the rise of money politics. 'Islamic' militia groups have been at least as ubiquitous in Yogyakarta as the notoriously chaotic and brutal satgas (paramilitary wing) of the now powerful PDI-P. Such Islamic-oriented militias include the Gerakan Pemuda Ka'bah (Ka'bah Youth Movement), loosely linked to the United Development Party (PPP), which was the New Order's official 'Islamic' party, and the Islamic Defence Front (FPI), itself allegedly associated with a number of Islamic political groupings. In East Java, the Banser militia, linked to former President Abdurrahman Wahid's Nahdlatul Ulama

34. Interview, 8 September 2001 . He even claims that he has the receipts to prove this.

35. Personal communication, 17 July 2002.

36. Interview, 8 September 2001.

37. Interview with Sotar Nasution, 3 September 2001. 
mass organization, is particularly feared. Some of these militias are widely believed to have underworld links. For example, it has been suggested that many are involved in protection rackets in collusion with corrupt local police forces. $^{38}$

In North Sumatra, racketeering is largely the domain of old New Order 'youth'/crime organizations like the Pemuda Pancasila (Pancasila Youth) - originally set up to help the military confront the Indonesian Communist Party in the 1960s - and its powerful local rival, the Ikatan Pemuda Karya (IPK; Functional Youth Group). A number of members from such organizations currently occupy local parliamentary seats across the province. Two have won post-Soeharto elections for bupati and mayor in North Sumatra. ${ }^{39}$ Clearly gaining in influence, these political gangsters have thus been among the main beneficiaries of decentralization and democracy in Indonesia. Many members of youth/crime organizations with historical links to both the military and the old ruling party, Golkar, have now migrated to other parties, or to their paramilitary wings, in search of new patrons in the context of the recent emergence of decentralized predatory networks. The bosses of the New Order-backed Pemuda Pancasila and IPK in North Sumatra, however, brush away this threat and deny that they are losing their muscle power to new competitors in the chaotic struggle for power and control over local resources. ${ }^{40}$ Other outfits, like the Pemuda Demokrat, ostensibly linked to the PDI-P, have members scattered across the political spectrum in the province, as well as in other youth organizations. ${ }^{41}$

These developments clearly have little to do with neo-institutionalist theoretical frameworks that strongly link decentralization, democracy, and good governance. Moreover, rather than empowering the most disadvantaged sections of civil society, as in the rhetoric, decentralization has largely taken off without them. This is apparent in the testimony of activists from a number of people's movements in North Sumatra: land rights activists argue that local governments which are supposed to be more accountable to local peoples have done little to resolve long-standing land tenure disputes involving the peasantry; labour activists suggest that political party-linked militia have been involved in terrorizing workers during labour disputes, while in the pay of local industrialists. $^{42}$ Clearly the problem for the peasantry and for labour is that, unlike

38. Interview with Herman Abdul Rahman, member of Yogyakarta provincial parliament for the PPP, 14 December 2000.

39. Interview with Amir Purba, Dean, Faculty of Social and Political Sciences, Islamic University of North Sumatra (UISU), 5 July 2001; and data compiled by Elfenda Ananda.

40. Respectively, Medan city parliamentarians Bangkit Sitepu and Moses Tambunan. Interviews, 11 July 2002.

41. Interview with Pemuda Demokrat leaders, Medan, 13 August 2002.

42. Interviews with Erwin Nasution, 6 July 2001, Effendi Pandjaitan, 18 July 2002, and Abnawi Nuh, 18 July 2002. 
organized gangs, they are unable to impose themselves on the local parties and parliaments running local government and the decentralization show.

\section{CONCLUSION}

There are of course limits to the way that the examples discussed above, mainly pertaining to the North Sumatran situation, can be generalized across the sprawling Indonesian archipelago. Local officials can certainly be found who have performed relatively well under difficult circumstances. In the town of Kebumen in Central Java, for instance, the mayor - elected in 2000 - has cracked down on local corruption (Straits Times, 8 September 2003). However, the infrequency with which such instances are reported suggests that the circumstances under which individuals gain and maintain power make it exceedingly difficult for a genuinely reformist impulse to take hold and not dissipate under the pressures of money politics and political thuggery, which have underpinned the workings of Indonesia's democracy, both nationally and locally.

Thus the point to be emphasized is that the decentralization process in Indonesia has largely been hijacked by interests that have little to gain from local governance characterized by greater accountability to local communities, transparency, and the like. Although the design of decentralization was faulty in the first place - being full of legal contradictions and ambiguities - this was not the main reason behind the process's deterioration. It was the persistence, and indeed 'victory', of predatory interests in contests over power that had the most important implications for decentralization (and local-level democratization) in Indonesia. The key was that these elements were not swept away by the fall of Soeharto, but managed to reinvent themselves in the new democracy. Thus, decentralization is unlikely to produce the kind of technocratic 'good' governance idealized in the neoinstitutionalist scheme. This is most vividly illustrated by the rise of political gangsters and thugs - perhaps the ultimate of predators - in the leadership of parties, parliaments and executive bodies at the local level. It is these sorts of interests that are now steering the decentralization agenda, not technocratic experts in the neo-Platonian mould.

The observations above contradict the assumptions of the neo-institutionalist literature on decentralization. While this literature is inclined to emphasize the element of 'choice', the case of Indonesia shows that the choices actually available to policy-makers are restricted by real constellations of power and interest. While neo-institutionalists tend to emphasize the technical aspects of decentralization, the case study shows that contests over power have a much greater impact on the way that decentralization takes place than intentional policy. Moreover, in contrast to neo-institutionalists' tendency to link processes such as decentralization, democracy, participation, accountability and the nurturance of civil society/social capital, the Indonesian case 
demonstrates that decentralization can be appropriated and captured by decidedly 'uncivil' groups. And finally, while neo-institutionalists envisage decentralization as part of a wider, albeit unacknowledged, political project in which technocratic expertise and 'rationality' win out through their own merits, the actual dynamics of politics can result in technocratic 'experts' and their allies being brushed aside as their programmes are appropriated by those who are more deeply entrenched, better organized and simply more powerful.

\section{REFERENCES}

Ahmad, Ehtisham and Bert Hofman (2000) 'Indonesia: Decentralization — Opportunities and Risks'. IMF and World Bank Resident Mission. Available online: http://www.imf.org/ external/pubs/ft/seminar/2000/idn/oprisk.pdf.

Asian Development Bank (ADB) (1999) 'Governance in Thailand: Challenges, Issues and Prospects' (April). Available online: http://www.eldis.org/static/DOC7222.htm.

Becker, Gary (1996) Accounting for Tastes. Cambridge, MA: Harvard University Press.

Bell, Gary F. (2001) 'The New Indonesian Laws Relating to Local Autonomy: Good Intentions, Confusing Laws', Asian-Pacific Law \& Policy Journal 2(1): 1-45.

Bourchier, David and Vedi R. Hadiz (eds) (2003) Indonesian Politics and Society: A Reader. London: Routledge.

Bourdieu, Pierre (1986) Distinction: A Social Critique of the Judgment of Taste. London: Routledge and Kegan Paul.

Chalmers, Ian and Vedi R. Hadiz (eds) (1997) The Politics of Economic Development in Indonesia: Contending Perspectives. London: Routledge.

Coleman, James (1988) 'Social Capital in the Creation of Human Capital', American Journal of Sociology 94 (Supplement): S95-S120.

Crook, Richard and James Manor (1998) Democracy and Decentralization in South Asia and West Africa. Cambridge, Cambridge University Press.

Fine, Ben (2001) Social Capital versus Social Theory: Political Economy and Social Science at the Turn of the Millennium. London: Routledge.

Harriss, John (2002) Depoliticizing Development: The World Bank and Social Capital. London: Anthem Press.

Hadiz, Vedi R. (2003) 'Power and Politics in North Sumatra: The Uncompleted Reformasi', in Edward Aspinall and Greg Fealy (eds) Local Power and Politics in Indonesia: Democratization and Decentralization, pp. 119-31. Singapore: Institute of Southeast Asian Studies.

Hutchcroft, Paul D. (1998) 'Sustaining Economic and Political Reform: The Challenges Ahead', in David G. Timberman (ed.) The Philippines: New Directions in Domestic Policy and Foreign Relations. New York, NY: Asia Society.

Jayasuriya, Kanishka (2000) 'Authoritarian Liberalism, Governance, and the Emergence of the Regulatory State in Post-Crisis East Asia', in Richard Robison, Mark Beeson, Kanishka Jayasuriya and Hyuk-Rae Kim (eds) Politics and Markets in the Wake of the Asian Crisis, pp. 315-30. London: Routledge.

Kompas (2000) 'Korupsi di Indonesia Paling Parah di Asia' ('Indonesian Corruption is the Worst in Asia') 23 March. Available online: http://www.kompas.com/kompas-cetak/0003/ 23/utama/koru01.htm

Litvack, Jennie, Junaid Ahmad and Richard Bird (1998) Rethinking Decentralization in Developing Countries. Washington, DC: The World Bank.

Malley, Michael (2001) 'Class, Region, Culture: The Sources of Social Conflict in Indonesia', in Nat J. Colletta, Teck Ghee Lim and Anita Kelles-Viitanen (eds) Social Cohesion and 
Conflict Prevention in Asia: Managing Diversity through Development, pp. 349-81. Washington, DC: The World Bank.

Manor, James (2002) The Political Economy of Democratic Decentralization. Washington, DC: The World Bank.

McVey, Ruth (ed.) (2000) Money and Power in Provincial Thailand. Singapore: Institute of Southeast Asian Studies.

Patpui, Sompong (1999) 'Decentralization Update' (29 October). Available online: http:// www.grassrootsthai.net/d1.htm.

Putnam, Robert D. (1993) Making Democracy Work: Civic Traditions in Modern Italy. Princeton, NJ: Princeton University Press.

Putnam, Robert D. (2000) Bowling Alone: The Collapse and Revival of American Community. New York, NY: Simon and Schuster.

Robison, Richard and Vedi R. Hadiz (2002) 'Oligachy and Capitalism: The Case of Indonesia', in Luigi Tomba (ed.) East Asian Capitalism: Conflicts, Growth and Crisis, pp. 37-74. Milan: Fondazione Giancomo Feltrinelli.

Robison, Richard and Vedi R. Hadiz (2004) Reorganising Power in Indonesia: The Politics of Oligarchy in an Age of Markets. London: RoutledgeCurzon.

Rodan, Garry (1996) 'Theorising Political Opposition in East and Southeast Asia', in Garry Rodan (ed.) Political Oppositions in Industrialising Asia, pp. 1-39. London: Routledge.

Rodan, Garry, Kevin Hewison and Richard Robison (2001) 'Theorising Southeast Asia's Boom, Bust and Recovery', in Garry Rodan, Kevin Hewison and Richard Robison (eds) The Political Economy of Southeast Asia: Conflicts, Crises, and Change, pp. 1-41. Melbourne: Oxford University Press.

Rood, Steven (1998) 'Decentralization, Democracy, and Development', in David G. Timberman (ed.) The Philippines: New Directions in Domestic Policy and Foreign Relations. New York, NY: Asia Society. Available online: http://www.asiasociety.org/publications/ philippines/decentralization.html

Simandjuntak, Robert A. (2003) 'Pinjaman Daerah: Kenapa Tidak?' ('Regional Borrowing: Why Not?'), Tempo Interaktif 01/XXXII: 3-9 March.

Weber, Max (1978) Economy and Society. Berkeley, CA: University of California Press.

White, Gordon (1994) 'Civil Society, Democratization and Development (I): Clearing the Analytical Ground', Democratization 1(3): 375-90.

World Bank (1996) 'Indonesia: Dimensions of Growth, Jakarta'. Country Department III, East Asia and Pacific Region. Washington, DC: The World Bank.

World Bank (2000) Working Together: The World Bank's Partnership with Civil Society. Washington, DC: The World Bank.

Wunch, James (1998) 'Decentralization, Local Governance and the Democratic Transition in Southern Africa: A Comparative Analysis', African Studies Quarterly: The Online Journal for African Studies 2(1). Available online: http://web.africa.ufl.edu/asq/v2/v2ila2.htm

Vedi R. Hadiz is Associate Professor in the Department of Sociology, National University of Singapore, Singapore 117570. He is the author of Workers and the State in New Order Indonesia (Routledge, 1997) and co-author of Reorganising Power in Indonesia: The Politics of Oligarchy in an Age of Markets (Routledge-Curzon, 2004). 
Copyright of Development \& Change is the property of Blackwell Publishing Limited and its content may not be copied or emailed to multiple sites or posted to a listserv without the copyright holder's express written permission. However, users may print, download, or email articles for individual use. 